\title{
Bimbingan Belajar Anak Usia Dini di Wilayah Pesisir Pantai Dusun Kuranji Bangsal Lombok Barat
}

\author{
Mega Safana $^{1^{*}}$, Khusnul Khotimah ${ }^{2}$, Siti Hajariah ${ }^{3}$, Nurfitriani Raodatul Jannah ${ }^{4}$, Gita Putri \\ Wahyuni $^{5}$, Sulastri ${ }^{6}$ \\ ${ }^{1,4,5}$ Fakultas Keguruan \& Ilmu Pendidikan,Universitas Mataram,Mataram, Indonesia; \\ ${ }^{2}$ Fakultas Teknik, Universitas Mataram,Mataram, Indonesia; \\ ${ }^{3}$ Fakultas Matematika \&Ilmu Pengetahuan Alam, Universitas Mataram,Mataram, Indonesia; \\ ${ }^{6}$ Fakultas Pertanian, Universitas Mataram,Mataram, Indonesia;
}

DOI: https://doi.org/10.29303/jpmsi.v2i2.47

Citation: Safana, M., Khotimah, K., Hajariah, S., Jannah, N.R., Wahyuni, G. P., Sulastri, S. 2020. Bimbingan Belajar Anak Usia Dini di Wilayah Pesisir Pantai Dusun Kuranji Bangsal Lombo Barat . Jurnal Pengabdian Masyarakat Sains Indonesia (JPMSI). 2(2):164-167 .

Article history

Received: October $07^{\text {th }} 2020$

Revised: October $20^{\text {th }} 2020$

Accepted: December $28^{\text {th }} 2020$

*Corresponding Author: Mega Safana, Universitas Mataram, Mataram, Indonesia. Email: megasfn14@gmail.com

Abstrak: Masa usia dini merupakan masa yang paling brilian yang dilalui oleh manusia. Pada masa usia dini manusia dapat belajar segalanya dalam waktu yang relatif singkat, untuk itu pendidikan usia dini disebut sebagai masa keemasan (golden age) dimana seluruh aspek perkembangan penting untuk aspek perkembangan selanjutnya. Anak merupakan investasi terbesar masa depan, sehingga sangat disayangkan jika pada masa pertumbuhan dan perkembangan anak dimasa keemasannya tidak fungsikan sebaik mungkin. Dusun Kuranji Bangsal terletak di Desa Kuranji Dalang, Kecamatan Labuapi, Kabupaten Lombok Barat yang terletak berdekatan dengan bibir pantai. Penduduk desa berjumlah 726 jiwa, jika dirata-ratakan sebagian besar tamatan SD bahkan belum sampai tamat. Rendahnya pendidikan di lokasi ini membuat penulis menggagas ide untuk mengadakan pengabdian kepada masyarakat yakni Bimbingan Belajar Anak Usia Dini. Kegiatan pengabdian masyarakat ini dilakukan selama 1 bulan penuh dari 25 Agustus - 25 September 2019. Kegiatan pengabdian masyarakat terdiri dari sosialisasi, bimbingan belajar dan pengenalan lingkungan.

Kata kunci: Pendidikan Usia Dini, Golden age, Dusun Kuranji Bangsal, Pendidikan, Bimbingan Belajar

\section{Pendahuluan}

Undang -undang Sistem Pendidikan Nasional tahun 2003 pasal 1 ayat 14, mengatakan bahwa upaya pembinaan yang ditunjukkan bagi anak usia 0-6 tahun dilakukan melalui Pendidikan Anak Usia Dini atau PAUD (Rozikan.2018). secara umum Pendidikan Anak Usia Dini adalah suatu upaya pembinaan dilakukan melalui pemberian rangsangan kepada anak. Pendapat lain menyatakan Pendidikan Anak Usia Dini merupakan salah satu bentuk satuan pendidikan yang hakekatnya diselenggarakan dengan tujuan untuk memfasilitasi pertumbuhan dan perkembangan anak secara menyeluruh atau menekankan pada pengembangan seluruh aspek kepribadian anak (Kemendikbud.2017).

Masa usia dini merupakan masa yang paling brilian yang dilalui oleh manusia. Pada masa usia dini manusia dapat belajar segalanya dalam waktu yang relatif singkat, untuk itu pendidikan usia dini disebut sebagai masa keemasan (golden age) dimana seluruh aspek perkembangan penting untuk aspek perkembangan selanjutnya (Trianto,2016). Anak merupakan investasi terbesar masa depan, sehingga sangat disayangkan jika pada masa pertumbuhan dan perkembangan anak dimasa keemasannya tidak fungsikan sebaik mungkin. 
Safana et al, Jurnal Pengabdian Masyarakat Sains Indonesia 2020, 2 (2):164-167. DOI : https://doi.org/10.29303/jpmsi.v2i2.47

Sehingga investasi terbaik sebagai penunjang anak untuk masa depannya adalah pendidikan.

Dusun Kuranji Bangsal terletak di Desa Kuranji Dalang, Kecamatan Labuapi, Kabupaten Lombok Barat. secara keseluruhan penduduk Dusun Kuranji Bangsal sebanyak 726 jiwa yang sebagian besar bermata pencaharian sebagai nelayan. Penduduk Dusun Kuranji Bangsal sebagian besar tingkat pendidikan Sekolah Dasar (SD) tetapi tidak tamat sebanyak 95 orang dan tamat SD sederajat 233 orang. Sebagian lagi SLTP/sederajat 56 orang sedangkan SLTA/sederajat 53 orang serta sarjana 6 orang. Melihat rendahnya minat pendidikan masyarakat setempat sangat disayangkan jika tidak dibagun sejak dini untuk memperbaiki generasi muda yang akan datang.

Keadaan diperparah dengan tidak adanya sarana pendidikan formal di wilayah tersebut . Sarana pendidikan di dusun tersebut hanya taman bermain Kanak-Kanak atau PAUD yang berdiri di tengah pemukiman warga dan berhadapan langsung dengan bibir pantai. Taman belajar kanak- kanak ini bernama "PAUD Sehat Cerdas Ceria" memiliki siswa sebanyak 22 orang terbagi menjadi 2 kelas. Tenaga pendidik sebanyak 3 orang yang mengajar anak- anak secara sukarela. Terdapat 4 mata pelajaran yang diajarkan yakni membaca, menulis, menggambar dan mengaji. Disamping itu pada setiap hari jumat pagi diawali dengan olahraga lalu mulai belajar.

Berdasarkan wawancara terhadap salah satu guru PAUD Sehat Cerdas Ceria mengatakan kekurangan tenaga ajar untuk membimbing siswa setiap harinya sehingga penulis berinisiatif untuk pengabdian kepada masyarakat yakni bimbingan belajar untuk anak usia dini di PAUD Sehat Cerdas Ceria. Adanya kegiatan ini diharapkan dapat membantu tenaga pendidik dan orang tua dalam bidang pendidikan baik formal, informal maupun nonformal dan dapat meningkatkan motivasi belajar anak.

\section{Metode}

Metode kegiatan pengabdian kepada masyarakat melalui program bimbingan belajar untuk anak usia dini dilaksanakan dengan tahapan sebagai berikut.
e-ISSN : 2715-2537

p-ISSN : 2715-2545

1. Tahap persiapan

a. Penentuan lokasi

Langkah pertama yang dilakukan adalah penentuan lokasi dengan melakukan pertimbangan-pertimbangan dan kriteria serta kebutuhan pada lokasi pengabdian.

b. Survei lokasi

Survei lokasi bertujuan untuk melihat latar belakang, kondisi dan permasalahan dari masyarakat terhadap pendidikan khususnya pada pendidikan anak-anak.

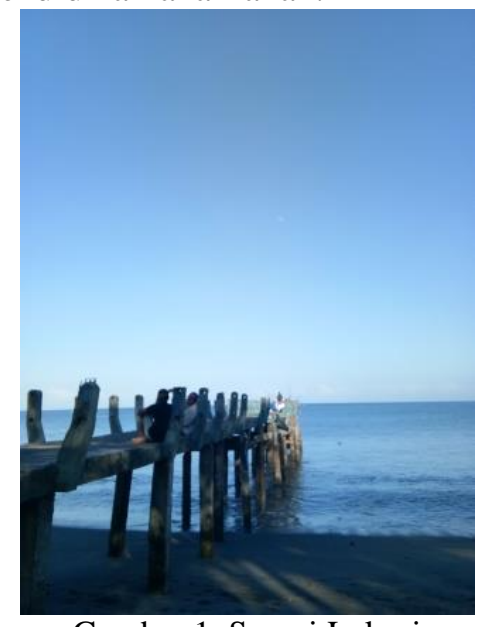

c. Perizinan

Melakukan perizinan bertujuan untuk menjalin hubungan dengan pihak yayasan agar kegiatan dapat berjalan dan terjalin dengan baik.

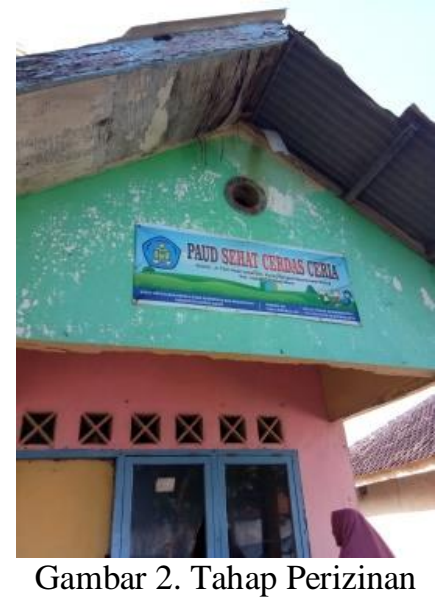

2. Tahap pelaksanaan kegiatan

a. Melakukan sosialisasi dan Pemberian motivasi

Sosialisadi dan pemberian motivasi dilakukan kepada tenaga ajar atau guru agar dapat sama-sama terus bersemangat untuk mendidik anak bangsa sebagai investasi, juga 
Safana et al, Jurnal Pengabdian Masyarakat Sains Indonesia 2020, 2 (2):164-167. DOI : https://doi.org/10.29303/jpmsi.v2i2.47

pemberian motivasi dilakukan kepada anakanak agar tetap semangat dalam belajar dengan stategi-startegi tertentu.

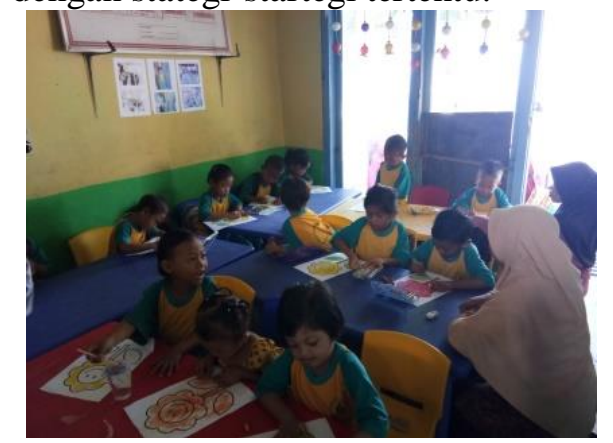

Gambar 3. Pemberian motivasi kepada siswa

b. Bimbingan belajar

Bimbingan belajar dilakukan setiap hari senin hingga jumat dimulai jam 08.00 10.30 WITA dengan materi yang berbedabeda setiap harinya.

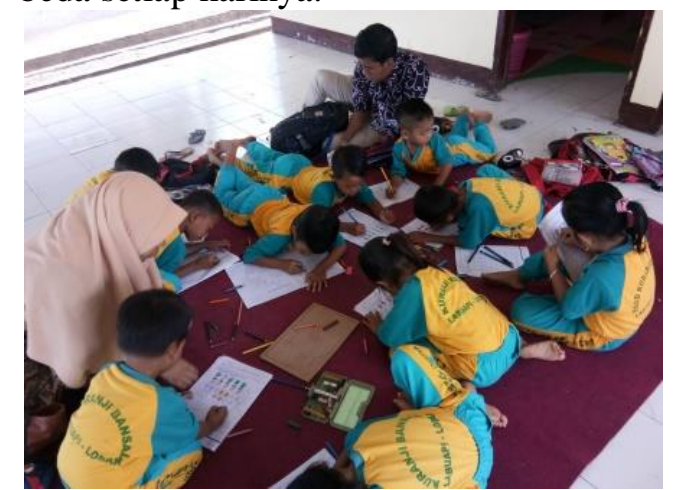

Gambar 4. Bimbingan Belajar

c. Pengenalan lingkungan

Pengenalan lingkungan dilakukan saat jam istirahat agar anak-anak dapat peka terhadap lingkungan sekitar.

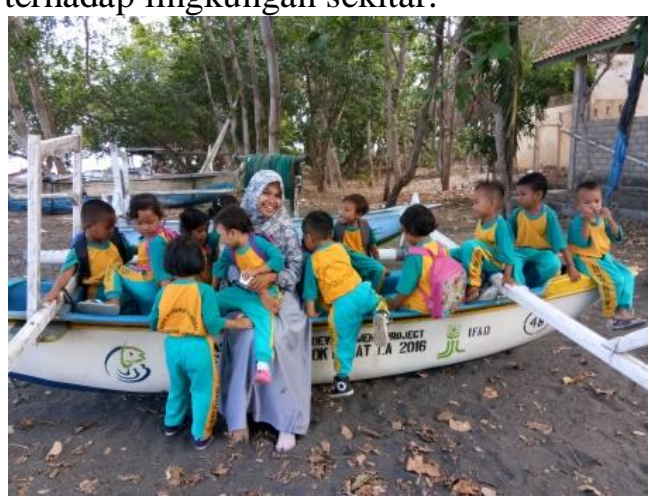

Gambar 5. Pengenalan Lingkungan

3. Tahap Akhir

a. Tahap Evaluasi

Tahap evaluasi dilakukan secara bertahap dan berkala dari kegiatan yang telah di
e-ISSN : 2715-2537

p-ISSN : 2715-2545

lakukan di evaluasi kekurangan-kekurangan pada kegiatan.

b. Penarikan Tutor

Tahapan ini merupakan tahap terakhir dalam kegiatan. Setelah melaksanakan program selama 1 bulan, diakadan tahap perpisahan, pemberian kenang-kenangan dan penarikan tutor dari mahasiswa Universitas Mataram.

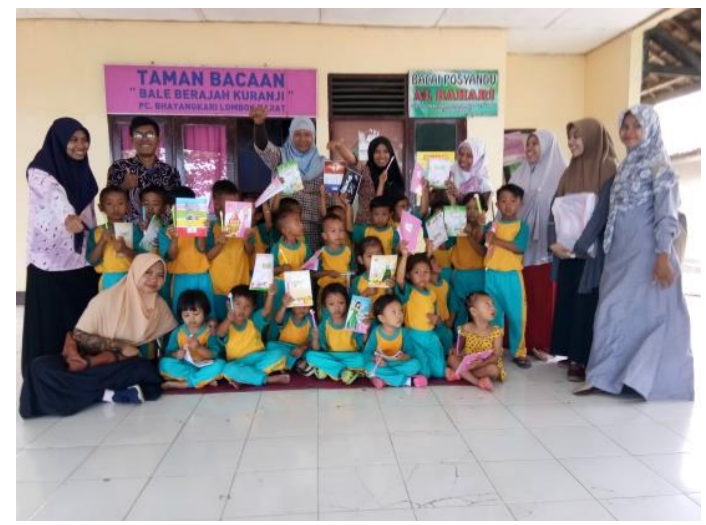

Gambar 6. Penarikan Tutor

\section{Hasil dan Pembahasan}

Hasil dari pelaksanaan kegiatan pengabdian masyarakat ini yakni dapat membantu tenaga ajar PAUD Sehat Cerdas Ceria dalam mengajar anakanak usia dini dan dapat memberikan penguatan bagi guru dan anak dalam belajar dan mengajar serta mahasiswa Universitas Mataram dapat menyalurkan ilmu pengetahuan yang dimiliki sebagai insan yang terpelajar.

Program bimbingan belajar anak usia dini dilaksanakan di Dusun Kuranji Bangsal, Desa Kuranji Dalang dinilai berjalan dengan baik. Langkah pertama yang dilakukan dalam menjalankan program ini adalah observasi daerah sasaran dan lokasi sasaran pengabdian yang bertujuan untuk mengetahui situasi dan kondisi serta permasalahan yang dialami. Langkah selanjutnya adalah melakukan perizinan program kepada pihak terkait dalam hal ini adalah kepada dusun dan pihak kepala yayasan. Respon dari pihak terkait sangat baik dan mendukung dalam pelaksanaan pengebdian.

Tujuan utama dalam melaksanakan program pengabdian masyarakat ini yakni sebagai wadah bagi Mahasiswa Universitas Mataram dalam menyalurkan ilmu pengetahuannya serta membangkitkan semangat juang untuk membangun bangsa salah satunya melalui mengajar anak 
Safana et al, Jurnal Pengabdian Masyarakat Sains Indonesia 2020, 2 (2):164-167. DOI : https://doi.org/10.29303/jpmsi.v2i2.47

bangsa. Demi terbentuknya masyarakat yang terpelajar maka dilaksanakan program Bimbingan Belajar Anak Usia Dini. Adapun kegiatan belajar mengajar dimulai dari pukul 08.00 sampai 11.30 Wita yang dilaksanakan pada hari senin sampai jum'at. Jumlah siswa yang mengikuti pembelajaran sebanyak 22 orang.

Terdapat 4 mata pelajaran yang diajarkan di dalam kelas yakni, membaca, menulis, menggambar dan mengaji. Sedangkan kegiatan diluar kelas yakni olahraga dan pengenalan lingkungan. Sebelum memulai pembelajaran siswa diwajibkan berdo'a bersama dan pengutan bagi anak-anak dengan memberikan stimulus dan pemberian motivasi lalu dilanjutkan dengan proses pembelajaran. Setelah dilaksanakannya proses pembelajaran, pada akhir pembelajaran dilakukan do'a bersama dan lagu daerah dalam melestarikan budaya.

\section{Kesimpulan}

Kesimpulan dari pelaksanaan kegiatan pengabdian kepada masyarakat ini adalah anakanak Taman Bacaan Bale Kuranji memiliki semangat yang tinggi dalam belajar. Pembelajaran yang dilakukan sangat beragam dan dapat menunjang pengetahuan yang akan datang.

\section{Saran}

Perlu diperhatikan tenaga ajar agar dapat membimbing anak-anak dengan baik serta menumbuhkan sikap dan rasa peka pada lingkungan dan masyarakat.

\section{Ucapan Terima Kasih}

Penulis mengucapkan terima kasih kepada UKM PRIMA Universitas Mataram yang telah memberi dukungan financial terhadap pengabdian ini.

\section{Daftar Pustaka}

Muhammad Rozikan. 2018. Penguatan Karakter Anak Usia Dini Melalui Bimbingan dan Konseling. Volume 4 no 2 (2018) halaman 204-214.

Kementrian Pendidikan dan Kebudayaan.2017. Model Pendidikan Formal dan
e-ISSN : 2715-2537

p-ISSN : 2715-2545

Informal. Pengembangan Pendidikan Anak Usia Dini dan Pendidikan Masyarakat. Jawa Barat.

Trianto. 2016. Desain Pengembangan Pembelajaran Tematik Bagi Anak Usia Dini. Jakarta: Perdana Media.

BKKBN.2017. Profil Dusun Kuranji Bangsal, Desa Kuranji Dalang, Kecamatan Labuapi Kabupaten Lombok Barat. URL:Kampungkb.bkkbn.go.id. Diakses pada tanggal 5 Juni 2020. 